\title{
THE IMPORTANCE OF TEACHING ACTIVITY IN THE PROCESS OF COGNITIVE PROCESSING
}

\author{
Ana - Georgiana CĂLUGĂRESCU ${ }^{1 *}$
}

\begin{abstract}
Received: January 2020 | Accepted: February 2020 | Published: April 2020
Please cite this paper as: Călugărescu, A-G. (2020). The Importance of teaching activity in the process of cognitive processing, Holistica Journal of Business and Public Administration, vol. 11, iss. 1, pp. 146-154
\end{abstract}

\begin{abstract}
Most young people have to adapt to society. More and more students have gaps in the communicative act, no real conditions about material or spiritual are known. More serious is that it is a very high percentage while it is dedicated to new technologies, while allocated it is being recreated in nature being increasingly reduced, reaching the final young people having problems adapting the place where they are in society. Building a connection between education and the environment, strengthening the connections between people and the influence of nature can have the physical health of the person but also mental health. Awareness of climate change for the last period and the desire for an opera can use phenomena that can be protected from the natural desert, produced more and more often.

Keywords: changes; education; evolution; management
\end{abstract}

\section{Introduction}

The education of young people at present is difficult due to the increasingly pronounced behaviors and the non-acceptance by the education actors, the rigid programs that they must respect. More and more young people want to learn without much effort or if they can study as little as possible because they say, "I do not use them in life". Although these ideas of theirs are difficult to accept, we, the teaching staff and especially society, must come to their aid, providing them with a most welcoming environment and diversifying teaching activity to the maximum.

There are many circumstances for training young people. The actions of different educational environments must be combined to adequately model behaviors and knowledge in accordance with the ideals of the time. One of the most important factors in developing children's behaviors is their families. The family represents the most natural

\footnotetext{
${ }^{1}$ Valahia University of Targoviste, Targoviste, Romania, m_ana_g@yahoo.com

* Corresponding author
} 
HOLISTICA Vol 11, Issue 1, 2020, pp. 146-154

environment possible and the one that exerts a huge influence, often implicitly, hidden. The child learns from this environment the first impressions, forming them by direct mimicry and contagion. Thus, the child will form his behavior following the steps of the parents.

At the same time, the educational institution in which the child is integrated is responsible for the education of the children. If in the first years of life, the child had only contact with family members, once they enter the school environment, they change behavior and mentally. Many children who come from families with a precarious material situation and with similar education but who self-educate during the school years.

Although the generations differ with each passing year, with their aspirations, needs, and abilities becoming more diverse, education goes at the same pace. The new school programs, designed to help young people, do nothing but wait for an increasingly dense fog over the educational act. For a teacher to succeed in a quality education he/she must prepare thoroughly before the beginning of each course.

From my point of view, it is not important the amount of material transmitted to the student but its quality and the percentage of understanding of the student. The entire educational activity must be carried out with the students and for them. Although school programs are becoming more and more crowded, the demands being higher, especially in certain subjects, we must realize that quality education can only be achieved when an increasing percentage of young people have succeeded in integrating into society.

\section{Main text}

\subsection{Principles and legalities of learning}

According to the explanatory dictionary, the term learning represents familiarity, getting used to new things or difficulties of life. At the same time, by learning we mean the acquisition of knowledge through study, the reaching by systematic work to the knowledge of a profession, sciences, languages, etc.

From the earliest ages, children can often have a unique way of behaving and functioning, thinking and communicating, moving and even processing sensory information in the environment (Dispenza, 2012, p. 186). These behaviors are thought-based and are based on human characteristics. There are physical and mental differences in students, students or even adults. Why one student can learn in a relatively short time while the other needs much more time for the same subject, why one student retains lessons, notions or even theories for simple teaching and the other cannot assimilate them even after a rehearsal for a long time, it represents the many questions from parents. These uncertainties are detailed by the principles, laws and functional mechanisms specific to human learning.

The law of activating the awareness of the learning action - it is the law that ignites the will of the concentration of each person to reach the learning purpose. A simple interrupt from the start of the learning activity of about 4.5 seconds triples the number of errors 
we can commit when we return to the main activity, and a deviation of 2.8 seconds doubles the error rate (Haltford, 2018, p. 106).

Thus it is important to achieve the purpose for which we learn, to have a maximum power of concentration avoiding the factors that may interfere and distract during the learning process. They are hardly avoided if they are dominated by the effects of pleasure. The neurological relief of the law is based on the awareness of the mechanisms and the assembly of the mental-mental elements mentioned, on the energetic mobilization generated by the projections regarding the final edifice of the learning under construction (Neacșu, 2019, p.108). Everyone needs a well-established purpose, a proactive behavioral attitude, a positive attitude from a mental point of view. In the absence of awareness, the brain system is in a relatively unknown state.

The specialists in the field study a new coefficient, the awareness coefficient, found through a scale of awareness assessment, with a structure defined by six dimensions: emotional, cognitive, physical, spiritual, social-relational awareness and self-awareness. Law of consciousness and clarity of purpose of learning activity - law involving the presence of dopamine. When a task is successfully performed the condition of that person is positive, confident. Conversely, if the proposed goals are not achieved, the anxiety state may block the person's activity or lead to relatively lower efficacy parameters. At this moment the motivation, or rather the motivation hierarchy (Berkman, 2012) intervenes, through which the operations of the high-order thinking that answer the question "why?", The operations of the tactical thinking answering the question "how?". Law of repetition - repetition means a connection, an accumulation of new information by association, by repetition. The desired result is the reminder of the routine structure or a new routine memory.

It is essential for the repetition to have a constant frequency, to present a high degree of understanding, to identify, finally, familiar and predictable stimuli to activate new networks of concepts. Although there are differences in the way of learning of the students, their level of understanding of the degree of accessibility of the information received, through the repetition activity the intellectual capacities of the students can be developed. The law of transference - learning is an activity also based on the similarity of structures or functions, more precisely by transferring the capacity of human psyche to use part of what has already been learned in a new learning or that can influence the learning of new forms of behavior, starting or helping with previous practice/learning forms (Neacșu, 2019, p.116). For a correct course, the student must establish his / her own goals and write them down, create connections with elements close to them, reflect on the course, review and adjust if this is required. It can also be used as a motivation statement so that the proposed objectives are achieved and in the end, it is important that the learning is repeated until the general goal is achieved.

Cialdini, R., recommends the value of adaptive behaviors according to which the explicit goals, especially in the formal learning, are assumed: public (being presented to colleagues or close persons), active (indicating in detail the steps to be followed), with 
effort (in critically and responsibly, whether or not the proposed objectives are met). The law of the state of preparation for learning - every activity undertaken by us requires effort, be it physical or mental. The learning activity requires attention, concentration, so previous training on the action to be taken. The power of memory due to the relations between the subject and the action represents the preparatory moment that allows the brain to be active and to take the command ( $\mathrm{s}$ ) for the future beginning of learning, as an effective action (Neacșu, 2019, p. 111).

The law of motivation - motivation is an essential element in the learning activity. This makes learning self-sustaining. At the same time, the motivation, which supports the temple, produces the energy needed for the act of learning, operates as a selective factor of goals and objectives. Once motivation is lacking, learning suffers from dissatisfaction, encounters barriers, frustrations, interruptions. Reverse connection law - any learning activity is based on feedback. For a correct analysis of the assimilated notions, the percentage of achievement of the proposed objectives, the quality of the progress made and the correlation of the contents it is obligatory to have an inverse connection, to receive approval from the qualified persons on the work performed. The approval by the teacher of the effort and the correctness of the assimilated information represents the process by which the student can make certain corrections, when appropriate, can improve the learning pace or even the detailed outline of his educational activity. Feedback is the necessary instrument for the positive changes of the students, their behaviors, ensuring the efficiency of the reorganization of knowledge, the quality of the educational activity. The transfer of the information received and then assimilated must be made in a positive way for the achievement of the school progress. It presents a progressive growth that depends so much on the student's personality but especially on his involvement in the educational activities but also on his own experiences, of the successes, of creative learning. Ultimately, the good news about all of these, for both individuals and organizations, is that learning is a learned behavior. Learning fast does not mean that you are the smartest person in the room. It means that you have learned how to learn! (Stan, 2018)

\subsection{Formal education - non-formal education}

At the level of the educational institution, education and instruction reach a stage of maximum development through the programmed, planned and methodical character of the educational instructional activities. The education is carried out in various forms, most often through joint activities, the contents transmitted are carefully selected according to psycho-pedagogical criteria, the educational activities are required to be structured respecting the didactic principles, the most relevant learning methods are dimensioned, the specific knowledge, skills, and behaviors must be appreciated and evaluated. (Cucoș, 2006, p.49). The school units aim to gradually introduce young people into the universe of knowledge, using increasingly diverse methods and techniques. At present, the everchanging changes in the field of technology make teachers need to be informed about 
them. More and more young people are exceeding certain teachers in the newly introduced fields, so education goes in the opposite direction.

The educational document must be viewed from all the points it reaches, whether formal, non-formal or informal. Regardless of the form of education brought to the student, the student must be able to discern the elements needed to achieve his / her own goals.

Formal education (from Latin "formal" - form, figure, model, legally organized, formal). It refers to all the systematic and organized educational actions, elaborated and carried out within specialized educational institutions (Patrichi, 2012). Formal education helps in permanent assimilation of knowledge and facilitates the development of skills and the introduction of the person in society. An essential aspect of formal education is assessment, which is of great help to school success (Apostu, 2018).

Dehaene believes that the people of the school must know and recognize the power of the brain and mind, which would ultimately lead to a new direction of learning, neuroeducation or neuropedagogy. Thus, projects will be developed for education through which the students direct their school situation through the power of motivation and the will to evolve. At the same time, teachers can train students' minds and develop the belief that success can come by proposing appropriate methodological strategies. At the same time, an important part of the educational activity is non-formal education. It includes all the educational influences, which take place outside the classroom (extrapara-extracurricular activities) or through optional or optional activities. The term nonformal denotes a less formalized or non-formalized educational reality, but always with formative effects (Cozma, 1988, p. 50).

Non-formal education comes to the aid of both young people and teachers, giving them the chance to interact with students, to create connections and to truly know the environment of origin, desires, and aspirations of each one. If in the school environment the teacher is constrained by the rigor that they impose, in the free environment he can decide on the knowledge that should be transmitted and according to each one to outline a wide range of these activities. What is new today about this way of educating young people lies in its planned organization. In some situations, non-formal education can be a way to help those who have a lower chance of accessing normal schooling: poor, isolated, residents of remote areas, illiterate, drifting youth, people with special needs (De Landsheere, 1992, p. 566).

Most of the time, the students refuse any contact with the school only because of the family from which they come. Although society is progressing at an accelerated pace, there is still a large percentage of families with precarious education who also offer similar education to young people. For the new generations to reach a mandatory average level of preparation, these young people need to be guided both in the family and in the schools. Many institutions do not declare the actual percentage of abandonment, thus wishing that the institution is placed in a favorable light compared to the larger institutions. This fact only results in the failure of the young people in life, their nonintegration into society and more seriously, the increase of the criminalities among them. 
It is known that a very large percentage of people arrested for acts of violence, theft, rape are people with poor education or no education.

It is not important for the student to keep as many formulas or memorize word-for-word any text taught by the teachers, but rather to know why they use this new information, how it can help it develop, how it can link the information provided by to us and how to get them to perform in the desired fields. Specifically, these influences are exercised through circles, competitions, school Olympics, and are initiated either by the school or by children's and youth organizations, parents' organizations, denominational organizations, etc. The activities are also dimensioned and coordinated by parents, etc. The activities are also coordinated and dimensioned by specialists but who play their roles more discreetly, often assuming the task of animators or moderators (Văideanu, 1998, p. 231).

The non-formal education is the one through which all the novelties are learned through the practice, in reality, it is the one with which you can introduce the students into a horizon of real knowledge, without a detour, without it being a maid. Often parents want to do a lot of homework for the students, not taking into account the fact that they feel neglected, neglected, unimportant or even powerless and ultimately risking the students to be scared of everything and say more and more times than I can not do certain things, exercises, tasks without trying, at least. The obstruction of the manifestations of creativity is due mainly to the hostile attitude of the parents, the educators manifested by irony, disregard, perfectionist claims, conformity, rigidity, exaggeration of the stakes of success or reward. Creating an atmosphere tense of suspicion, of fear of not succeeding, fear of not being at the height of expectations and demands prejudices the manifestation of creativity. Also, the false atmosphere of exaltation in the face of mediocre results contributes to the creation and maintenance of illusions whose disruption is painfully experienced (Macavei, 2001, p. 213).

A broad approach is taken to validate in Scotland. Not only is it formally embedded in the qualifications and credit system, but there is a recognition that developing the use of validation processes needs practical support, as well as clarity of thought about how best to support learners. It is probably no accident that this is underpinned by a strong focus on collaboration that involves the full range of stakeholders - another important lesson from Scotland (McCoshan, 2016). Non-formal education automatically responds to concrete needs of action, offers the first moment of abstraction by extracting knowledge from practice, facilitates contact with knowledge, starting from the needs felt by education, dramatizes the teaching function (Cucoș, 2006, p.47).

The creation of more and more outdoor activities for students and teachers is straining the connections between them, the students not being forced to learn, this fact coming from their initiative. In the learning process, we distinguish two stages: the first one is to solve a problem - now the main role is thought, organizing perception, memory, and imagination - and in the second stage, fixing, consolidating the solution, and intelligent memory (Cosmovici, 2008, p. 129). 
The expansion of education in contemporary society inevitably leads to the amplification of the investigations undertaken in this field. Education is approached from multiple angles, multidisciplinary and interdisciplinary (Nicola, 2003, p. 80). At present, the educational activity is no longer based on the theoretical notions from the teachers, but it falls on observational, experimental, applied research, methods by which the student discovers alone and tests the results on his own experience.

\section{Discussion and Conclusions}

Learning is different and each student has their style of remembering, remembering, thinking or even analyzing. If the educational activity is focused on the students for whom it is undertaken and not on the didactic material offered to them, the student has much greater chances of success. There is more and more talk about poor student performance at national exams, but do these exams express a student's intelligence level?

In answering the question, from my point of view, the results obtained from the nationally supported assessments are the same as the "grinding" level of these children. For a correct and relevant evaluation, a diversification of the exams is needed, a multidisciplinary approach. Although a student does not do well in the exact sciences, he can be a good translator or a good speaker, he has focused on the humanities and each other. Never, most students can learn all subjects at the maximum level. There is a relatively small percentage compared to the number of students who can have great results, regardless of the subject.

For the small number of students with special results, the other students are asked the same or more and more seriously, the other students are compared to them: "why $X$ managed to achieve this result and you do not?" - is the question of more and more parents without to realize that at that moment he is mocking, discouraging and throwing the student into a state of anxiety.

Learning is different and each student has their style of remembering, remembering, thinking or even analyzing. If the educational activity is focused on the students for whom it is undertaken and not on the didactic material offered to them, the student has much greater chances of success. There is more and more talk about poor student performance at national exams, but do these exams express a student's intelligence level?

In answering the question, from my point of view, the results obtained from the nationally supported assessments are the same as the "grinding" level of these children. For a correct and relevant evaluation, a diversification of the exams is needed, a multidisciplinary approach. Although a student does not do well in the exact sciences, he can be a good translator or a good speaker, he has focused on the humanities and each other. Never, most students can learn all subjects at the maximum level. There is a relatively small percentage compared to the number of students who can have great results, regardless of the subject. 
HOLISTICA Vol 11, Issue 1, 2020, pp. 146-154

For the small number of students with special results, the other students are asked the same or more and more seriously, the other students are compared to them: "why $X$ managed to achieve this result and you do not?" - is the question of more and more parents without to realize that at that moment he is mocking, discouraging and throwing the student into a state of anxiety.

Those who hold information also have their power and, therefore, the ability to influence, to their advantage, the course of events. (Petrescu, 2018, p. 73). Due to the society in the process of evolution, change, development, the students present must be aware that the future depends on the quantity and quality of information assimilated throughout the school.

At the same time, the socialization within the educational institution can affect the character of the students. Connie Wanberg defines the process of organizational socialization as "the process by which individuals acquire the knowledge, skills, attitudes, and behaviors they are seeking to adopt" (2012, p. 17).

A good teacher not only uses verbal language but also non-verbal language. The parallel image follows the vocal indicators that accompany verbal communication (Wood, 2014, p. 132). The student is attentive at all times both to oral communication with him but also to the body language and, as a rule, imitates certain gestures of the teachers, especially those that represent a model for him. The speed we are talking about is not a given value; thus, there is no certain rhythm of exposure that would make communication effective. A good communicator will know how to vary this speed depending on the recipients of the message and the message itself (Pânișoara, 2016, p.108). Analogously, the student must understand what a teacher has to offer, must be able to speak in the sense of all, even if they have different reception styles. Another disadvantage presented by the schools in Romania is that of a large number of students in the same class. Gerguț, 2007, considers that the control capacity within an organization is directly related to the number of subordinates that a single person can supervise. Regardless of how young people are educated, the teacher must learn the information provided, train the students' behaviors so that in the future they will bring further development to the respective society and find educational methods and means to reduce school dropout and help all students equally.

\section{References}

Apostu, D. (2018). Formal-non-formal-informal education, available at https://edict.ro/educatiaformala-nonformala-informala/

Berkman, E. (2012). Goals Motivation and the Brain, Psychology Today, available at https://www.psychologytoday.com/us/blog/the-motivated-brain/201211/goalsmotivation-and-the-brain.

Cialdini, R. (2010). Persuasion Psychology, Business Tech Publishing House: Bucharest.

Cosmovici, A., \& lacob, L. (2008). School Psychology, Polirom Publishing House: Iași.

Cozma, T. (1988). School and parallel education, Al. I. Cuza: lasi.

Cucoș, C. (2006). Pedagogy, Polirom Publishing House, lași 
HOLISTICA Vol 11, Issue 1, 2020, pp. 146-154

Dehaene, S. (2007). The neurons of reading, Odile Jacob: Paris.

Dspenza, J. (2012). Train your brain: strategies and techniques for mental transformation, Curtea veche Publishing House: Bucharest.

Gherguț, A. (2007). General and strategic management in education, Polirom Publishing House: Iași

Halford, S. (2018). Active brain for life and profession, Niculescu Publishing House: Bucharest

Landsheere, V. De. (1992). Education and Training, PUF: Paris

Macavei, E. (2001). Theory of education, Aramis Publishing House: Bucharest

McCoshan, A.(2016). Validation of non-formal and informal learning - a holistic approach by Scotland, available at https://epale.ec.europa.eu/en/blog/validation-non-formal-andinformal-learning -holistic-approach-Scotland

Neacșu, I. (2019). Neurodidactics of learning and cognitive psychology, Polirom Publishing House: lași

Nicola, I. (2003). Treatise on school pedagogy, Aramis Publishing House: Bucharest

Patrichi, M. (2012). Formal, non-formal and informal education, available at https://iteach.ro/pg/blog/mariana.patrichi/read/32476/educatia-formala-nonformala-siinformala

Pânișoara, G. (2016). Human resources management, Polirom Publishing House: Iași

Petrescu, M. (2018). Information security management, Bibliotheca Publishing House: Târgoviște

Stan, S. (2018). Learning is a learning behavior, available at https://www.learningnetwork.ro/articol/invatarea-este-un-comportament-care-seinvata/4315

Vaideanu, G. (1998). Education at the border between millennia, Political Publishing House, București

Wanberg, C. (2012). The Oxford Handbook of Organizational Socialization, Oxford University Press: New York

Wood, J. T. (2014). Gendered Lives, Cengage Learning: New York 